\title{
Pengaruh Motivasi, Gaya Kepemimpinan Transformasional dan Budaya Organisasi Terhadap Kinerja Karyawan Melalui Kepuasan Kerja Sebagai Variabel Intervening Studi Pada PT. Champion Kurnia Djaja Technologies
}

\author{
Setria Feri \\ Universitas Lancang Kuning Pekanbaru \\ Adi Rahmat \\ Universitas Lancang Kuning Pekanbaru \\ Bambang Supeno \\ Universitas Lancang Kuning Pekanbaru \\ setriaf@gmail.com
}

\begin{abstract}
Abstrak
Mengelola sumber daya manusia di dalam perusahaan berarti mengelola pegawai agar dapat menghasilkan kinerja yang optimal untuk mencapai tujuan organisasi. Kinerja adalah hasil kerja secara kualitas dan kuantitas yang dicapai oleh seorang pegawai dalam melaksanakan tugasnya sesuai dengan tanggung jawab yang diberikan kepadanya. Tujuan dari kajian ini adalah menganalisis pengaruh motivasi, gaya kepemimpinan transformasional dan budaya organisasi terhadap kinerja karyawan melalui kepuasan kerja sebagai variabel intervening terhadap karyawan PT. Champion Kurnia Djaja Technologies. Analisis jalur (path analysis) digunakan untuk menguji model yang dihipotesiskan secara statistik dengan bantuan SPSS-19, serta untuk menentukan sejauh mana model yang diajukan tersebut konsisten dengan data sampel. Hasil penelitian ini menunjukkan bahwa motivasi, gaya kepemimpinan transformasional dan budaya organisasi masing-masing berpengaruh positif dan signifikan terhadap kepuasan kerja. Motivasi berpengaruh negatif dan signifikan terhadap kinerja karyawan. Kepemimpinan transformasional, budaya organisasi dan kepuasan kerja masingmasing berpengaruh positif dan signifikan terhadap kinerja karyawan di PT. Champion Kurnia Djaja Technologies. Kepuasan kerja mampu bertindak sebagai variabel intervening untuk memediasi hubungan motivasi terhadap kinerja karyawan. Sementara, untuk hubungan gaya kepemimpinan transformasional dan budaya organisasi terhadap kinerja karyawan, pengaruh kepuasan kerja sebagai variabel intervening tidak sebesar pengaruh langsungnya.
\end{abstract}

Kata Kunci: Motivasi, gaya kepemimpinan transformasional, budaya organisasi, kepuasan kerja, kinerja karyawan.

\section{Pendahuluan}

PT. Champion Kurnia Djaja Technologies (CKDT) adalah sebuah perusahaan swasta yang bergerak di bidang penyedia bahan kimia dan jasa pengolahan minyak dan gas bumi. Di provinsi Riau, PT. CKDT beroperasi di lingkungan PT. Chevron Pacific Indonesia yang meliputi wilayah Minas, Petapahan dan Duri serta termasuk juga wilayah West Seno di lepas pantai Kalimantan Timur. Peranan PT. CKDT berhubungan erat dengan proses produksi minyak dan gas bumi, penentuan kualitas yang dihasilkan, serta pemeliharaan sistem proses pengaliran minyak di dalam pipa-pipa dan tanki-tanki milik PT. Chevron Pacific Indonesia untuk semua wilayah tersebut. Agar dapat bertahan dalam menghadapi persaingan bisnis terhadap perusahaan sejenis lainnya, PT. CKDT berupaya memberikan pelayanan yang baik melalui peningkatan kinerja karyawan guna meningkatkan kinerja perusahaan. 
Berdasarkan teori Hierarki Kebutuhan Maslow, meningkatkan pemenuhan kebutuhan karyawan pada tingkat yang lebih tinggi dapat memotivasi karyawan dan menciptakan iklim kerja yang menyenangkan, pada gilirannya akan meningkatkan kinerja yang lebih baik (Edison dkk, 2018: 179). Sebagai faktor utama dalam memenuhi kebutuhan fisiologis, faktor gaji sangat berperan dalam mempengaruhi tingkat motivasi karyawan dalam bekerja. Berdasarkan data penelitian, struktur dan jumlah gaji yang diterima karyawan lapangan di PT. CKDT setiap bulannya sudah berada di atas upah minimum regional provinsi Riau tahun 2020 sehingga diharapkan dapat memenuhi kebutuhan hidup dan meningkatkan motivasi kerja karyawan.

Di dalam organisasi, pemimpin memiliki peran yang kuat dalam membangun dan menumbuhkan semangat motivasi di kalangan karyawan. Menurut Hamali (2018: 132) tugas dari setiap pemimpin adalah untuk memastikan bahwa karyawan memiliki derajat motivasi yang tinggi. Karyawan yang termotivasi akan memiliki tingkat produktivitas kerja dan kinerja yang tinggi. Menurut Edison dkk (2018: 87), pemimpin adalah seseorang yang memiliki bawahan atau pengikut untuk suatu tujuan dan keberhasilannya sangat dipengaruhi oleh kepemimpinan yang dimilikinya. Keberhasilan atau kegagalan dalam mencapai tujuan organisasi banyak ditentukan oleh gaya kepemimpinan seseorang dalam mengelola sumber daya yang ada. Dari gaya kepemimpinan inilah suasana lingkungan kerja sangat ditentukan. Tabel 1 di bawah ini adalah data penggantian pimpinan yang terjadi di PT. CKDT selama periode tahun 2017 s.d. 2019. PT. CKDT sangat serius dalam menjaga kualitas kepemimpinan di perusahaannya karena dapat mempengaruhi kinerja karyawan. Dengan kepemimpinan yang baik kinerja karyawan tentu akan dapat ditingkatkan.

Tabel 1. Data Penggantian Pimpinan di PT. Champion Kurnia Djaja Technologies Wilayah Operasi PT. Chevron Pacific Indonesia

\begin{tabular}{|c|c|c|l|}
\hline $\begin{array}{c}\text { No } \\
\cdot\end{array}$ & $\begin{array}{c}\text { Tahu } \\
\mathbf{n}\end{array}$ & $\begin{array}{c}\text { Jumlah } \\
\text { Penggantia } \\
\text { n Pimpinan }\end{array}$ & \multicolumn{1}{c|}{ Keterangan } \\
\hline 1 & 2017 & 2 & $\begin{array}{l}\text { 1 kali penggantian manajer proyek di area Minas dan 1 kali } \\
\text { penggantian insinyur kimia di area Duri }\end{array}$ \\
\hline 2 & 2018 & 5 & $\begin{array}{l}\text { 2 kali penggantian suvervisor di area Minas, 1 kali } \\
\text { penggantian insinyur kimia di area Duri, 2 kali penggantian } \\
\text { insinyur kimia di area West Seno }\end{array}$ \\
\hline 3 & 2019 & 7 & $\begin{array}{l}\text { 2 kali penggantian manajer proyek di area Duri, 2 kali } \\
\text { penggantian supervisor di area Duri, 2 kali penggantian } \\
\text { supervisor di area Minas dan 1 kali penggantian manajer } \\
\text { proyek di area West Seno. }\end{array}$ \\
\hline
\end{tabular}

(Sumber data: PT. CKDT kantor cabang Pekanbaru, 2020)

Seperti halnya kepemimpinan dan motivasi, budaya organisasi juga sangat penting di dalam organisasi karena budaya organisasi menyediakan kerangka kerja terkait dengan perilaku anggota dan iklim kerja. Apabila budaya organisasi kuat, anggota yang ada di dalam organisasi menganggap aturan bukan lagi sebagai kewajiban yang membelenggu, tetapi sudah menjadi kebutuhan. Di sisi lain, mereka memiliki rasa kebersamaan, kekeluargaan, dan bangga pada organisasinya yang pada gilirannya menumbuhkan komitmen organisasi dan kepuasan kerja (Edison dkk, 2018: 115). 
Tabel 2 berikut ini adalah data tingkat kehadiran karyawan tahun 2017 s.d. 2019 yang dapat mencerminkan tingkat motivasi dan budaya kerja yang baik di PT. CKDT.

Tabel 2. Tingkat Kehadiran Karyawan PT. Champion Kurnia Djaja Technologies

\begin{tabular}{|c|c|c|c|c|c|c|}
\hline Tahun & $\begin{array}{c}\text { Jumlah } \\
\text { Karyawa } \\
\text { n (Orang) }\end{array}$ & $\begin{array}{c}\text { Jumlah } \\
\text { Hari } \\
\text { Kerja } \\
\text { (Hari) }\end{array}$ & $\begin{array}{c}\text { Jumlah Hari } \\
\text { Kerja } \\
\text { Seharusnya } \\
\text { (Hari) }\end{array}$ & $\begin{array}{c}\text { Julah } \\
\text { Hari } \\
\text { Kerja } \\
\text { Yang } \\
\text { Hilang } \\
\text { (Hari) }\end{array}$ & $\begin{array}{c}\text { Tingkat } \\
\text { Kehadira } \\
\text { naryawan } \\
\text { (\%) }\end{array}$ & $\begin{array}{c}\text { Tingkat } \\
\text { Absensi } \\
\text { Karyawa } \\
\text { n } \\
(\%)\end{array}$ \\
\hline 2017 & 111 & 12.293 & 12.361 & 68 & $99,45 \%$ & $0,55 \%$ \\
\hline 2018 & 111 & 27.704 & 27.999 & 295 & $98,95 \%$ & $1,05 \%$ \\
\hline 2019 & 116 & 28.545 & 28.844 & 299 & $98,96 \%$ & $1,04 \%$ \\
\hline (Sumber data: PT. CKDT kantor cabang Pekanbaru, 2020) \\
\hline
\end{tabular}

Berdasarkan kajian literatur, penelitian yang dilakukan oleh Dharma (2017), Agus (2017), Maghfirah (2015) dan Antasurya (2013) menyimpulkan bahwa motivasi memiliki pengaruh positif dan signifikan terhadap kinerja karyawan. Hasil penelitian lain yang dilakukan oleh Diamantidis (2018) menyimpulkan bahwa motivasi intrinsik secara langsung mempengaruhi kinerja karyawan. Berbeda dengan penelitian yang dilakukan oleh Parmin (2015) yang menyimpulkan bahwa motivasi tidak berpengaruh signifikan terhadap kinerja karyawan.

Penelitian yang dilakukan oleh Pawirosumarto et al. (2017), menyimpulkan bahwa gaya kepemimpinan berpengaruh paling positif dan signifikan terhadap kinerja karyawan. Sedangkan menurut hasil penelitian yang dilakukan oleh Agus (2017), Masadeh et al. (2016), dan Maghfirah (2015), menyimpulkan bahwa gaya kepemimpinan transformasional berpengaruh positif dan signifikan terhadap kinerja karyawan. Paracha et al. (2012) menyimpulkan bahwa kepemimpinan transformasional berhubungan dengan kinerja karyawan tetapi pengaruhnya tidak sebesar kepemimpinan transaksional. Sementara, Maryati et al. (2019) menyimpulkan bahwa kepemimpinan spiritual tidak mempengaruhi kinerja karyawan.

Penelitian yang dilakukan oleh Parmin (2015) dan Antasurya (2013), menyimpulkan bahwa kepuasan kerja berpengaruh positif dan signifikan terhadap kinerja karyawan. Namun, hasil penelitian yang dilakukan oleh Setiawan (2013) menyimpulkan bahwa kepuasan kerja tidak berpengaruh secara signifikan terhadap kinerja karyawan. Bahkan, penelitian lain yang dilakukan oleh Pawirosumarto et al. (2017), menyimpulkan bahwa kepuasan kerja tidak bertindak sebagai variabel mediasi antara lingkungan kerja, gaya kepemimpinan, dan budaya organisasi terhadap kinerja karyawan.

Berdasarkan uraian fakta dan research gap tersebut diatas, mendorong untuk dilakukan penelitian mengenai pengaruh motivasi, gaya kepemimpinan transformasional dan budaya organisasi terhadap kinerja karyawan melalui kepuasan kerja sebagai variabel intervening di PT. Champion Kurnia Djaja Technologies. 


\section{Landasan Teori}

\section{Kinerja}

Kinerja adalah hasil kerja secara kualitas dan kuantitas yang dicapai oleh seorang pegawai dalam melaksanakan tugasnya sesuai dengan tanggung jawab yang diberikan kepadanya (Mangkunegara, 2017: 67). Kinerja merupakan suatu fungsi dari motivasi dan kemampuan untuk menyelesaikan tugas atau pekerjaan, dimana seseorang sepatutnya memiliki derajat kesediaan dan tingkat kemampuan tertentu (Gaol 2014: 273).

Menurut Edison dkk (2018: 193), sebagai indikator tolok ukur kinerja karyawan adalah: (1) Target pemenuhan jumlah barang, pekerjaan, atau jumlah uang yang dihasilkan; (2) Kualitas terhadap hasil yang dicapai; (3) Penyelesaian pekerjaan yang tepat waktu; (4) Taat asas, yaitu melakukan pekerjaan dengan benar, transparan dan dapat dipertanggungjawabkan.

\section{Kepuasan Kerja}

Robbins dalam Wibowo (2016: 415) menyatakan bahwa kepuasan kerja adalah sikap umum terhadap pekerjaan seseorang yang menunjukkan perbedaan antara jumlah penghargaan yang diterima pekerja dan jumlah yang diyakini oleh pekerja yang seharusnya mereka terima.

Menurut Kreitner dan Kinicki dalam Wibowo (2016: 417) terdapat lima faktor yang dapat mempengaruhi timbulnya kepuasan kerja, yaitu: (1) Need fulfillment (pemenuhan kebutuhan); (2) Discrepancies (perbedaan), yaitu pemenuhan harapan yang mencerminkan perbedaan antara apa yang diharapkan dan yang diperoleh individu dari pekerjaan; (3) Value attainment (pencapaian nilai); (4) Equity (keadilan); (5) Dispositional / genetic components (komponen genetik), yaitu keyakinan bahwa kepuasan kerja sebagian merupakan fungsi sifat pribadi dan faktor genetik.

\section{Motivasi}

Koldakar dalam Hamali (2018: 131) mendefinisikan motivasi sebagai hasrat dalam yang membakat yang disebabkan oleh kebutuhan, keinginan, dan kemauan yang mendorong seorang individu untuk menggunakan energi fisik dan mentalnya guna tercapainya tujuantujuan yang diinginkan.

Menurut Edison dkk (2018: 174), Abraham Maslow mengelompokkan lima jenjang kebutuhan yang tersusun dalam suatu hierarki yang menjadi dimensi dari motivasi, yaitu: (1) Physiological needs (Kebutuhan fisiologis); (2) Safety needs (Kebutuhan rasa aman); (3) Affection needs (Kebutuhan untuk disukai); (4) Esteem need (Kebutuhan harga diri); dan (5) Self-actualization needs (Kebutuhan pengembangan diri).

\section{Gaya Kepemimpinan Transformasional}

Kepemimpinan transformasional adalah gaya kepemimpinan yang menginspirasi, membangkitkan dan mengubah orang-orang atau karyawan dengan visi dan semangat untuk mencapai suatu tujuan dengan menyuntikkan antusiasme dan energi untuk menyelesaikan sesuatu. (Yang \& Islam, 2012: 388).

Dikutip dari Yang dan Islam (2015: 389-400), karakteristik kepemimpinan transformasional yang signifikan adalah sebagai berikut: 
(1) Karisma; Pemimpin memiliki karisma pribadi yang dapat mempengaruhi orang lain. Karisma tersebut timbul dari prestasi, sikap dan ketangkasan kerja pimpinan dalam menangani berbagai hal.

(2) Visi; Pemimpin memiliki visi yang jelas tentang perkembangan masa depan organisasi yang dapat diterima seluruh anggota dan membuat mereka terdorong untuk bekerja secara sungguh-sungguh.

(3) Motivasi; Pemimpin dapat merangsang minat anggota untuk melakukan upaya yang lebih besar untuk menyelesaikan misi organisasi dengan strategi yang dikomunikasikan dengan baik kepada anggotanya.

(4) Stimulasi intelektual; Pemimpin menuntun anggotanya untuk mengeksplorasi pengetahuan baru dan menggunakan pendekatan baru untuk berpikir dan menyelesaikan masalah, serta memungkinkan anggotanya untuk berbagi dan bertukar keterampilan dan pengalaman kerja.

(5) Pertimbangan individual; Pemimpin memiliki kepedulian, menghargai kerja keras dan mengatasi keluhan para anggotanya, serta memahami dan memberikan dukungan terhadap kemunduran dan kesulitan yang dihadapi anggotanya.

\section{Budaya Organisasi}

Menurut Robbins dan Coulter dalam Edison dkk (2018: 118), budaya organisasi merupakan nilai-nilai bersama, prinsip, tradisi, dan cara-cara dalam melakukan sesuatu yang mempengaruhi cara anggota organisasi dalam bertindak.

Menurut Edison dkk (2018: 129) terdapat lima dimensi budaya organisasi yang harus dipenuhi untuk menunjang kinerja, yaitu: kesadaran diri, keagresifan, kepribadian, performa, dan orientasi tim.

\section{Kerangka Konseptual Penelitian}

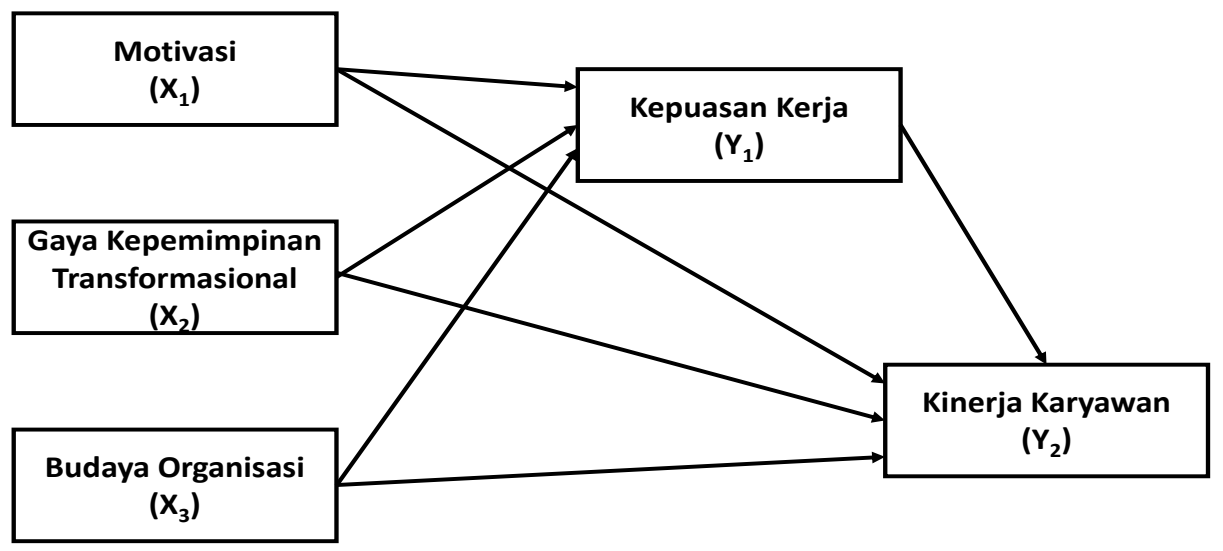

Gambar 1. Kerangka Konseptual Penelitian

Pengaruh Motivasi, Gaya Kepemimpinan Transformasional dan Budaya Organisasi Terhadap Kinerja Karyawan Melalui Kepuasan Kerja Sebagai Variabel Intervening Studi Pada PT. Champion Kurnia Djaja Technologies 


\section{Hipotesis Penelitian}

Berdasarkan kerangka konseptual maka hipotesis penelitian ini adalah sebagai berikut:

1. Diduga motivasi berpengaruh terhadap kepuasan kerja karyawan di lingkungan kerja PT. CKDT.

2. Diduga gaya kepemimpinan transformasional berpengaruh terhadap kepuasan kerja karyawan di lingkungan kerja PT. CKDT.

3. Diduga budaya organisasi berpengaruh terhadap kepuasan kerja karyawan di lingkungan kerja PT. CKDT.

4. Diduga motivasi berpengaruh terhadap kinerja karyawan di lingkungan kerja PT. CKDT.

5. Diduga gaya kepemimpinan transformasional berpengaruh terhadap kinerja karyawan di lingkungan kerja PT. CKDT.

6. Diduga budaya organisasi berpengaruh terhadap kinerja karyawan di lingkungan kerja PT. CKDT.

7. Diduga kepuasan kerja berpengaruh terhadap kinerja karyawan di lingkungan kerja PT. CKDT.

8. Diduga motivasi berpengaruh terhadap kinerja melalui kepuasan kerja karyawan di lingkungan kerja PT. CKDT.

9. Diduga gaya kepemimpinan transformasional berpengaruh terhadap kinerja melalui kepuasan kerja karyawan di lingkungan kerja PT. CKDT.

10. Diduga budaya organisasi berpengaruh terhadap kinerja melalui kepuasan kerja karyawan di lingkungan kerja PT. CKDT.

\section{Metode Penelitian}

\section{Rancangan Penelitian}

Penelitian ini didasarkan kepada persepsi responden yang didapatkan dari hasil survei menggunakan kuesioner terstruktur dalam bentuk pertanyaan atau pernyataan tertutup. Kuesioner dirancang menggunakan skala Linkert untuk mengukur perilaku, opini dan persepsi karyawan sesuai dengan fenomena sosial yang terjadi di lingkungan kerja PT. CKDT. Penelitian ini dilakukan dari tanggal 05 Mei 2020 sampai dengan 15 Juli 2020.

\section{Populasi dan Sampel}

Populasi dari penelitian ini adalah karyawan PT. CKDT wilayah operasi PT. Chevron Pacific Indonesia yang berjumlah sebanyak 116 orang yang terdiri dari 18 orang karyawan tetap dan 98 orang karyawan kontrak PKWT. Penentuan jumlah sampel merujuk pada tabel penentuan jumlah sampel Sugiyono (2019: 139) dengan taraf kesalahan 5\% dan metode purposive sampling. Penelitian ini direalisasikan dengan mengambil sampel sebanyak 98 orang orang karyawan kontrak PKWT. Teknik purposive sampling bertujuan untuk mendapatkan sampel yang homogen yang hanya terdiri dari karyawan kontrak PKWT di PT. CKDT.

\section{Teknik Pengumpulan Data}

Teknik pengumpulan data penelitian ini adalah dengan cara wawancara, kuesioner, observasi langsung dan kombinasi dari semua teknik tersebut. Teknik pengumpulan data dengan kuesioner dilakukan untuk memperoleh data deskriptif yang dikuantifikasikan untuk menguji hipotesis dengan model skala Linkert yang mempunyai 5 (lima) alternatif jawaban untuk masing-masing pertanyaan atau pernyataan yang diajukan dalam kuesioner sesuai dengan indikator-indikator yang telah ditetapkan. 


\section{Metode Analisis Data}

Metode analisis data yang digunakan dalam penelitian ini adalah dengan model Analisis Jalur (Path Analysis) dengan bantuan SPSS-19. Terdapat beberapa langkah pengujian yang dilakukan dalam penelitian ini, diantaranya: analisis deskriptif variabel penelitian, uji kualitas intrumen penelitian menggunakan uji validitas \& uji reliabilitas, uji normalitas, uji linieritas, dan analisis data menggunakan analisis regresi berganda, uji-F, uji-t dan uji-R. Dengan model analisis jalur (path analysis) selanjutnya dilakukan analisis pengaruh langsung dan pengaruh tak langsung dari variabel-variabel yang diuji.

Pengolahan data penelitian dimulai dengan seleksi dan penyaringan data yang dilakukan secara manual untuk mengetahui data yang layak untuk dianalisis. Untuk mendapatkan normalitas dan linieritas data di dalam analisis statistik penelitian ini dilakukan transformasi data dan screening yang bertujuan untuk mendeteksi adanya data outlier. Menurut Ghozali (2018: 40), outlier adalah data yang memiliki karakteristik unik yang terlihat sangat berbeda jauh dari observasi-observasi lainnya dan muncul dalam bentuk nilai ekstrim dan tidak terdistribusi secara normal. Data yang dianggap sebagai outlier, akan dikeluarkan dari uji statistik selanjutnya.

\section{Hasil Penelitian}

\section{Hasil Analisis Deskriptif Penelitian}

Hasil analisis deskriptif penelitian menunjukkan interpretasi tanggapan responden mengenai variabel-variabel penelitian yaitu variabel motivasi, gaya kepemimpinan transformasional, budaya organisasi, kepuasan kerja dan kinerja karyawan di PT. Champion Kurnia Djaja Technologies. Berdasarkan tabel 3 berikut ini menunjukkan bahwa interpretasi jawaban responden untuk semua variabel penelitian adalah tinggi.

Tabel 3. Hasil Analisis Deskriptif Penelitian

\begin{tabular}{|c|l|c|c|c|c|c|c|c|}
\hline $\begin{array}{c}\text { No } \\
\cdot\end{array}$ & \multicolumn{1}{|c|}{ Variabel } & $\mathbf{N}$ & Min & Max & $\begin{array}{c}\text { Mea } \\
\mathbf{n}\end{array}$ & $\begin{array}{c}\text { Standa } \\
\mathbf{r} \\
\text { Deviasi }\end{array}$ & $\begin{array}{c}\text { Skala } \\
\text { Interval }\end{array}$ & $\begin{array}{c}\text { Keteranga } \\
\mathbf{n}\end{array}$ \\
\hline 1 & Motivasi & 74 & 2,67 & 5,00 & 4,12 & 0,698 & $\begin{array}{c}1,77 \mathrm{~s} / \mathrm{d} \\
4,26\end{array}$ & Tinggi \\
\hline 2 & $\begin{array}{l}\text { Gaya } \\
\text { Kepemimpinan } \\
\text { Transformasional }\end{array}$ & 74 & 2,42 & 5,00 & 3,96 & 0,740 & $\begin{array}{c}1,56 \mathrm{~s} / \mathrm{d} \\
4,33\end{array}$ & Tinggi \\
\hline 3 & $\begin{array}{l}\text { Budaya } \\
\text { Organisasi }\end{array}$ & 74 & 3,00 & 5,00 & 4,36 & 0,516 & $\begin{array}{c}1,22 \mathrm{~s} / \mathrm{d} \\
3,90\end{array}$ & Tinggi \\
\hline 4 & Kepuasan Kerja & 74 & 2,67 & 5,00 & 3,99 & 0,627 & $\begin{array}{c}1,61 \mathrm{~s} / \mathrm{d} \\
4,22\end{array}$ & Tinggi \\
\hline 5 & Kinerja Karyawan & 74 & 3,00 & 5,00 & 4,33 & 0,486 & $\begin{array}{c}1,00 \mathrm{~s} / \mathrm{d} \\
3,91\end{array}$ & Tinggi \\
\hline
\end{tabular}

Sumber: Hasil pengolahan data dengan SPSS 


\section{Hasil Uji Validitas}

Uji validitas dilakukan terhadap semua butir-butir pertanyaan dari variabel penelitian dengan cara membandingkan $\mathbf{r}_{\text {hitung }}$ dengan $\mathbf{r}_{\text {tabel. }}$. Jika $\mathbf{r}_{\text {hitung }}>\mathbf{r}_{\text {tabel }}$ dan nilainya positif, maka butir pertanyaan tersebut dinyatakan valid (Ghozali, 2018: 52), dan jika $\mathbf{r}_{\text {hitung }}<\mathbf{r}_{\text {tabel }}$ maka butir pertanyaan tersebut dinyatakan tidak valid. Berdasarkan hasil analisis penelitian ini semua butir-butir pertanyaan atau indikator penelitian yang berjumlah 50 butir dinyatakan valid.

\section{Hasil Uji Reliabilitas}

Kuesioner yang memiliki tingkat reliabilitas yang baik adalah yang memiliki nilai koefisien Alpha Cronbach minimum 0,7 (Bahri, 2018: 118). Berdasarkan hasil analisis dinyatakan bahwa seluruh nilai koefisien Alpha Cronbach dari indikator penelitian ini lebih besar dari 0,7 sehingga semua indikator penelitian dinyatakan reliabel.

\section{Hasil Uji Normalitas}

Menurut Sugiyono (2019: 211), jenis data yang digunakan untuk analisis parametris adalah data interval. Perubahan data dari bentuk ordinal menjadi data interval dilakukan dengan metode MSI. Selanjutnya data ditransformasikan kedalam bentuk logaritma natural (Ln) untuk memenuhi normalitas dan linieritas data sehingga dilakukan juga perubahan label dari variabel penelitian menjadi: Ln_Mot untuk variabel motivasi, Ln_KEP untuk variabel gaya kepemimpinan tranformasional, Ln_BUD untuk variabel budaya organisasi, Ln_KPS untuk variabel kepuasan kerja dan Ln_KIN untuk variabel kinerja karyawan. Data akhir yang memenuhi uji normalitas dan linieritas berjumlah 74 data sampel penelitian.

Tabel 4. Sub Struktur Variabel Uji Normalitas

\begin{tabular}{|c|c|c|}
\hline Model & Independen Variabel & Dependen Variabel \\
\hline Sub Struktur I & Ln_MOT, Ln_KEP, Ln_BUD & Ln_KPS \\
\hline Sub Struktur II & $\begin{array}{c}\text { Ln_MOT, Ln_KEP, Ln_BUD, } \\
\text { Ln_KPS }\end{array}$ & Ln_KIN \\
\hline
\end{tabular}

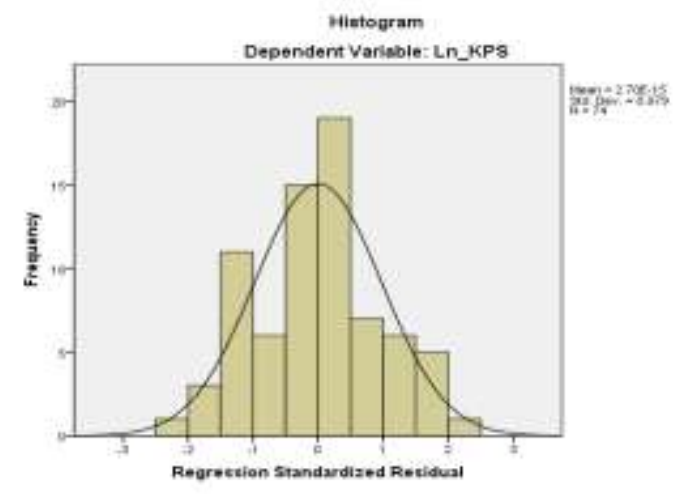

Gambar 2. Grafik Histogram Uji Normalitas Sub Struktur I

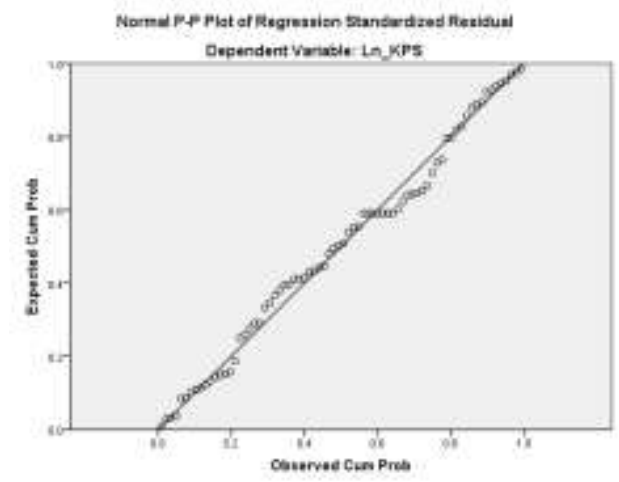

Gambar 3. Grafik P-Plot Uji Normalitas Sub Struktur I 


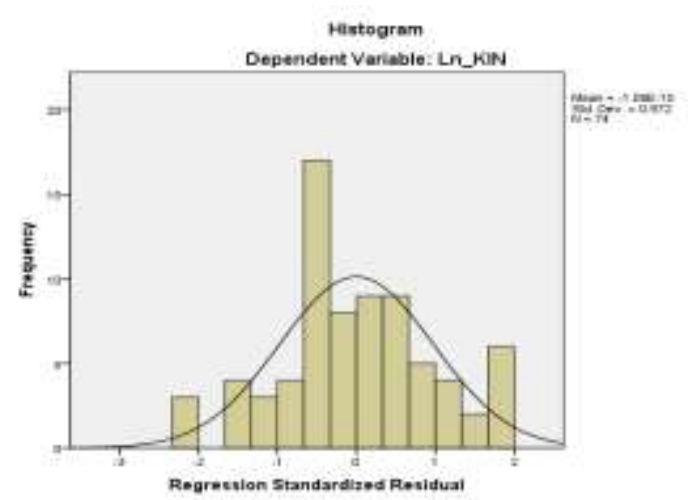

Gambar 4. Grafik Histogram Uji Normalitas Sub Struktur II

Sumber: Hasil pengolahan data dengan SPSS

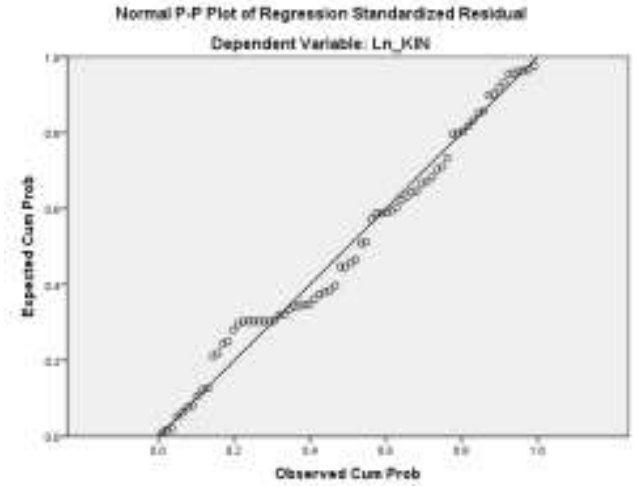

Gambar 5. Grafik P-Plot Uji Normalitas Sub Struktur II

\section{Hasil Uji Linieritas}

Tabel 5. Hasil Uji Linieritas Variabel Penelitian

\begin{tabular}{|c|lr|c|c|c|}
\hline No & Variabel & $\begin{array}{c}\text { Linierity } \\
\text { (sig) }\end{array}$ & $\begin{array}{c}\text { Deviation from Linierity } \\
\text { (Sig) }\end{array}$ & Keterangan \\
\hline 1 & $\begin{array}{l}\text { Ln_MOT } \\
\text { Ln_KPS }\end{array}$ & $\rightarrow$ & 0,000 & 0,055 & Linier \\
\hline 2 & $\begin{array}{l}\text { Ln_KEP } \\
\text { Ln_KPS }\end{array}$ & $\rightarrow$ & 0,000 & 0,225 & Linier \\
\hline 3 & $\begin{array}{l}\text { Ln_BUD } \\
\text { Ln_KPS }\end{array}$ & $\rightarrow$ & 0,000 & 0,816 & Linier \\
\hline 4 & $\begin{array}{l}\text { Ln_MOT } \\
\text { Ln_KIN }\end{array}$ & $\rightarrow$ & 0,000 & 0,151 & Linier \\
\hline 5 & $\begin{array}{l}\text { Ln_KEP } \\
\text { Ln_KIN }\end{array}$ & $\rightarrow$ & 0,000 & 0,404 & Linier \\
\hline 6 & $\begin{array}{l}\text { Ln_BUD } \\
\text { Ln_KIN }\end{array}$ & $\rightarrow$ & 0,000 & 0,943 & Linier \\
\hline 7 & $\begin{array}{l}\text { Ln_KPS } \\
\text { Ln_KIN }\end{array}$ & 0,000 & 0,017 & Linier parsial \\
\hline
\end{tabular}

Sumber: Hasil pengolahan data dengan SPSS

\section{Hasil Uji Regresi}

Tabel 6. Koefisien Regresi Hasil Uji Sub Struktur I

\begin{tabular}{|c|c|c|c|c|c|c|}
\hline \multirow{2}{*}{\multicolumn{2}{|c|}{ Model }} & \multicolumn{2}{|c|}{ Unstandardized Coefficients } & $\begin{array}{l}\text { Standardized } \\
\text { Coefficients }\end{array}$ & \multirow[t]{2}{*}{$t$} & \multirow[t]{2}{*}{ Sig. } \\
\hline & & B & Std. Error & Beta & & \\
\hline \multirow{4}{*}{1} & (Constant) & 0,120 & 0,090 & & 1,324 & 0,190 \\
\hline & Ln_MOT & 0,416 & 0,053 & 0,292 & 7,837 & 0,000 \\
\hline & Ln_KEP & 0,323 & 0,025 & 0,502 & 12,881 & 0,000 \\
\hline & Ln_BUD & 0,178 & 0,021 & 0,272 & 8,522 & 0,000 \\
\hline \multicolumn{7}{|c|}{ Dependent Variabel: Ln_KPS } \\
\hline \multirow{2}{*}{\multicolumn{2}{|c|}{$\begin{array}{l}\mathrm{R} \\
\mathrm{R} \text { Square } \\
\text { Adiusted R Square }\end{array}$}} & \multirow{2}{*}{\multicolumn{2}{|c|}{$\begin{array}{l}=0,985 \\
=0,971\end{array}$}} & $F$ hitung & \multicolumn{2}{|l|}{$=786,28$} \\
\hline & & & & F tabel & \multicolumn{2}{|l|}{$=2,74$} \\
\hline \multirow{2}{*}{\multicolumn{2}{|c|}{$\begin{array}{l}\text { Adjusted R Square } \\
\text { Std. Error of the Estimate }\end{array}$}} & \multicolumn{2}{|l|}{$=0,970$} & Sig. F & \multicolumn{2}{|l|}{$=0,000$} \\
\hline & & \multicolumn{2}{|l|}{$=0,15932$} & $\mathrm{t}$ tabel & \multicolumn{2}{|l|}{$=1,994$} \\
\hline
\end{tabular}

Sumber: Hasil pengolahan data dengan SPSS 
Tabel 7. Koefisien Regresi Hasil Uji Sub Struktur II

\begin{tabular}{|c|c|c|c|c|c|c|}
\hline & \multirow{2}{*}{ Model } & \multicolumn{2}{|c|}{ Unstandardized Coefficients } & $\begin{array}{l}\text { Standardized } \\
\text { Coefficients }\end{array}$ & \multirow[t]{2}{*}{$\mathrm{t}$} & \multirow[t]{2}{*}{ Sig. } \\
\hline & & B & Std. Error & Beta & & \\
\hline \multirow{5}{*}{1} & (Constant) & 0,105 & 0,143 & & 0,736 & 0,464 \\
\hline & Ln_MOT & $-0,259$ & 0,113 & $-0,136$ & $-2,282$ & 0,026 \\
\hline & Ln_KEP & 0,186 & 0,072 & 0,215 & 2,585 & 0,012 \\
\hline & In_BUD & 0,508 & 0,046 & 0,580 & 10,940 & 0,000 \\
\hline & Ln_KPS & 0,474 & 0,186 & 0,354 & 2,544 & 0,013 \\
\hline \multicolumn{7}{|c|}{ Dependent Variabel: Ln KIN } \\
\hline \multirow{3}{*}{\multicolumn{2}{|c|}{$\begin{array}{l}\text { R } \\
\text { R Square } \\
\text { Adjusted R Square }\end{array}$}} & \multirow{2}{*}{\multicolumn{2}{|c|}{$\begin{array}{l}=0,981 \\
=0,962\end{array}$}} & $F$ hitung & \multicolumn{2}{|l|}{$=430,82$} \\
\hline & & & & F tabel & \multicolumn{2}{|l|}{$=2,50$} \\
\hline & & \multicolumn{2}{|l|}{$=0.959$} & Sig. F & \multicolumn{2}{|l|}{$=0,000$} \\
\hline \multicolumn{2}{|c|}{ Std. Error of the Estimate } & \multicolumn{2}{|l|}{$=0,24853$} & $t$ tabel & $=1,994$ & \\
\hline
\end{tabular}

Sumber: Hasil pengolahan data dengan SPSS

\section{Koefisien Jalur dan Persamaan Struktural}

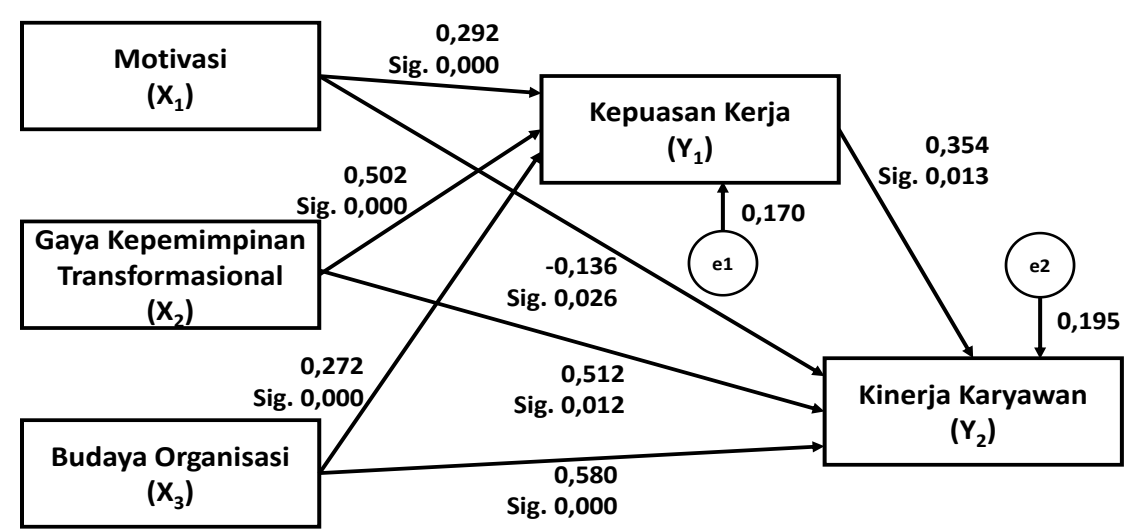

Gambar 6. Diagram Analisis Jalur

\section{Persamaan Struktural}

Persamaan Sub Struktur I:

$\operatorname{Ln} *(38,51-Y 1)=0,292 * \operatorname{Ln}(38,87-X 1)+0,502 * \operatorname{Ln}(52,48-X 2)+0,272 * \operatorname{Ln}(43,41-X 3)+0,170$

Persamaan Sub Struktur II:

$\operatorname{Ln} *(35,71-Y 2)=-0,136 * \operatorname{Ln}(38,87-X 1)+0,215 * \operatorname{Ln}(52,48-X 2)+0,580 * \operatorname{Ln}(43,41-X 3)+$ $0,354 * \operatorname{Ln}(38,51-Y 1)+0,195$ 
Setria Feri, Adi Rahmat, Bambang Supeno

Hasil Uji Hipotesis

Tabel 8. Hasil Uji Hipotesis Penelitian

\begin{tabular}{|c|c|c|c|c|c|c|c|}
\hline HIPOTESIS & VARIABEL & $\begin{array}{l}\text { PENGARUH } \\
\text { LANGSUNG }\end{array}$ & $\%$ & $\begin{array}{l}\text { PENGARUH } \\
\text { TIDAK } \\
\text { LANGSUNG }\end{array}$ & $\%$ & $\begin{array}{l}\text { PENGARUH } \\
\text { TOTAL }\end{array}$ & $\%$ \\
\hline 1 & $X_{1} \ldots Y_{1}$ & 0,292 & 29,20 & & & 0,292 & 29,2 \\
\hline 2 & $X_{2} \ldots Y_{1}$ & 0,502 & 50,20 & & & 0,502 & 50,2 \\
\hline 3 & $X_{3} \ldots Y_{1}$ & 0,272 & 27.20 & & & 0,272 & 27.2 \\
\hline 4 & $X 1 \ldots Y 2$ & $-0,136$ & $-13,60$ & & & $-0,136$ & $-13,6$ \\
\hline 5 & $x_{2} \rightarrow Y_{2}$ & 0,215 & 21,50 & & & 0,215 & 21.5 \\
\hline 6 & $X_{3} \ldots Y_{2}$ & 0,580 & 58,00 & & & 0,580 & 58,0 \\
\hline 7 & $Y_{1} \ldots Y_{2}$ & 0,354 & 35,40 & & & 0,354 & 35,4 \\
\hline 8 & $X 1 \ldots$ Y2 Melalui Y1 & $-0,136$ & $-13,60$ & 0,103 & 10,34 & $-0,033$ & $-3,3$ \\
\hline 9 & $X_{2} \rightarrow Y_{2}$ Melalui $Y_{1}$ & 0,215 & 21,50 & 0,178 & 17,77 & 0,393 & 39,3 \\
\hline 10 & $X_{3} \rightarrow Y_{2}$ Melalui Y1 & 0,580 & 58,00 & 0,096 & 9,63 & 0,676 & 67,6 \\
\hline
\end{tabular}

Sumber: Hasil pengolahan data dengan SPSS

\section{Pembahasan}

\section{Pengaruh Motivasi Terhadap Kepuasan Kerja}

Motivasi berpengaruh positif dan signifikan terhadap kepuasan kerja. Hasil pengujian hipotesis ini dibuktikan dengan nilai $t_{\text {hitung }}(7,837)>t_{\text {tabel }}(1,994)$. Besarnya pengaruh motivasi terhadap kepuasan kerja adalah 0,292 atau sebesar 29,2\% dianggap signifikan yang dibuktikan dengan taraf signifikansi $0,000<0,05$.

Hasil penelitian ini menunjukkan bahwa dengan meningkatkan motivasi maka kepuasan kerja juga akan meningkat. Hal ini sesuai dengan pendapat Koldakar dalam Hamali (2018: 131) yang mendefinisikan motivasi sebagai hasrat dalam yang membakat yang disebabkan oleh kebutuhan, keinginan, dan kemauan yang mendorong seorang individu untuk menggunakan energi fisik dan mentalnya guna tercapainya tujuan-tujuan yang diinginkan. Dengan tercapainya tujuan-tujuan yang diinginkan tersebut maka kepuasan kerja juga akan terpenuhi.

Berdasarkan hasil uji deskriptif penelitian ini, indikator-indikator yang paling mempengaruhi motivasi untuk meningkatkan kepuasan kerja karyawan di PT. Champion Kurnia Djaja Technologies adalah agar pimpinan tidak membeda-bedakan karyawan dan semuanya mendapatkan perhatian yang sama. Indikator lainnya adalah agar pimpinan selalu memberikan dukungan penuh kepada karyawannya untuk pengembangan diri.

\section{Pengaruh Gaya Kepemimpinan Transformasional Terhadap Kepuasan Kerja}

Gaya kepemimpinan transformasional berpengaruh positif dan signifikan terhadap kepuasan kerja. Hasil pengujian hipotesis ini dibuktikan dengan nilai thitung $(12,881)>t_{\text {tabel }}$ $(1,994)$. Besarnya pengaruh kepemimpinan transformasional terhadap kepuasan kerja adalah 0,502 atau sebesar 50,2\% dianggap signifikan yang dibuktikan dengan taraf signifikansi 0,000 $<0,05$.

Hasil penelitian ini menunjukkan bahwa dengan meningkatkan fungsi kepemimpinan transformasional maka kepuasan kerja juga akan meningkat. Hal ini sesuai dengan hasil penelitian yang dilakukan oleh Puni et al. (2018) yang menyimpulkan bahwa kepemimpinan transformasional berpengaruh positif terhadap kepuasan kerja, serta hasil penelitian yang dilakukan oleh Yang \& Islam (2012) yang menyimpulkan bahwa gaya kepemimpinan 
transformasional (pemeliharaan, perilaku pencapaian tujuan kelompok, dan saling melengkapi) benar-benar membantu meningkatkan kepuasan kerja karyawan.

Berdasarkan hasil uji deskriptif penelitian ini, indikator-indikator yang paling mempengaruhi fungsi gaya kepemimpinan transformasional untuk meningkatkan kepuasan kerja karyawan di PT. Champion Kurnia Djaja Technologies adalah agar pimpinan menjaga karisma di mata bawahan. Pimpinan diharapkan agar mensosialisasikan visi, misi dan perkembangan masa depan perusahaan bersama karyawan. Pimpinan diharapkan untuk meningkatkan komunikasi dengan anggotanya tentang cara-cara mencapai tujuan perusahaan. Pimpinan diharapkan untuk meningkatkan perhatiannya terhadap kebutuhan karyawan dalam bekerja. Selain itu, pimpinan juga diharapkan untuk meningkatkan upaya dalam membangun kepercayaan para karyawan untuk kemajuan perusahaan.

\section{Pengaruh Budaya Organisasi Terhadap Kepuasan Kerja}

Budaya organisasi berpengaruh positif dan signifikan terhadap kepuasan kerja. Hasil pengujian hipotesis ini dibuktikan dengan nilai $t_{\text {hitung }}(8,522)>t_{\text {tabel }}(1,994)$. Besarnya pengaruh budaya organisasi terhadap kepuasan kerja adalah 0,272 atau sebesar 27,2\% dianggap signifikan yang dibuktikan dengan taraf signifikansi $0,000<0,05$.

Hasil penelitian ini menunjukkan bahwa dengan menciptakan budaya organisasi yang baik dalam bekerja maka kepuasan kerja akan meningkat. Hal ini sesuai dengan pendapat Edison dkk (2018: 115), bahwa apabila budaya organisasi kuat, anggota yang ada dalam organisasi menganggap aturan bukan lagi sebagai kewajiban yang membelenggu, tetapi sudah menjadi kebutuhan. Di sisi lain, mereka memiliki rasa kebersamaan, kekeluargaan, dan bangga pada organisasinya yang pada gilirannya menumbuhkan komitmen organisasi dan kepuasan kerja.

Berdasarkan hasil uji deskriptif penelitian ini, indikator-indikator yang paling berpengaruh dalam menciptakan budaya organisasi yang baik untuk meningkatkan kepuasan kerja karyawan di PT. Champion Kurnia Djaja Technologies adalah dengan cara meningkatkan inisiatif karyawan dalam bekerja agar tidak selalu bergantung pada petunjuk pimpinan dalam menyelesaikan pekerjaan yang seharusnya bisa dilakukan sendiri oleh karyawan. Peningkatan inisiatif ini bisa dilakukan dengan cara melakukan bimbingan dan melalui pelatihan peningkatan kompetensi karyawan.

\section{Pengaruh Motivasi Terhadap Kinerja Karyawan}

Motivasi berpengaruh negatif dan signifikan terhadap kinerja karyawan. Hasil pengujian hipotesis ini dibuktikan dengan nilai $t_{\text {hitung }}(2,282)>t_{\text {tabel }}(1,994)$. Besarnya pengaruh motivasi terhadap kinerja karyawan adalah $-0,316$ atau sebesar $-31,6 \%$ dianggap signifikan yang dibuktikan dengan taraf signifikansi sebesar 0,026 $<0,05$.

Hasil penelitian ini menunjukkan bahwa motivasi berpengaruh negatif terhadap kinerja karyawan di lingkungan kerja PT. Champion Kurnia Djaja Technologies. Dengan demikian dapat digambarkan bahwa model korelasi linier hubungan motivasi terhadap kinerja karyawan cenderung miring ke arah kiri. Sedangkan model korelasi linier yang diharapkan adalah bernilai positif atau dengan garis korelasi yang miring ke arah kanan.

Berdasarkan hasil analisis deskriptif penelitian ini, terdapat tiga indikator kinerja karyawan skala terendah dengan frekuensi terbanyak yang dipilih oleh responden. Hasil deskriptif tersebut mengindikasikan bahwa masih ada responden yang merasakan hal-hal sebagai berikut: 
- Target pekerjaan yang diterima karyawan kurang menantang dan kurang realistis.

- Kualitas kerja yang dihasilkan karyawan belum sesuai dengan standar yang sudah ditetapkan.

- Masih ada karyawan yang belum tepat waktu dalam menyelesaikan target pekerjaannya.

Berdasarkan analisis dan simulasi statistik, ketiga indikator tersebut di atas sangat berperan dalam menentukan pengaruh motivasi terhadap kinerja karyawan. Dengan memenuhi ketiga indikator tersebut maka akan dapat merubah pengaruh motivasi terhadap kinerja karyawan dari linier negatif menjadi linier positif. Sebagai langkah perbaikan untuk ketiga indikator tersebut maka dapat dilakukan dengan cara:

- Melakukan rotasi secara berkala sehingga karyawan akan mendapatkan suasana baru yang lebih menantang dalam bekerja.

- Memberikan pelatihan berkala kepada karyawan sehingga karyawan lebih terampil dalam bekerja dan menghasilkan kualitas kerja sesuai dengan standar yang sudah ditetapkan.

- Memberikan target waktu penyelesaian pekerjaan, melakukan pengontrolan dan mengevaluasi kinerja karyawan secara berkala sehingga karyawan menjadi lebih disiplin dan dapat menyelesaikan pekerjaannya secara tepat waktu.

\section{Pengaruh Gaya Kepemimpinan Transformasional Terhadap Kinerja Karyawan}

Gaya kepemimpinan transformasional berpengaruh positif dan signifikan terhadap kinerja karyawan. Hasil pengujian hipotesis ini dibuktikan dengan nilai $t_{\text {hitung }}(2,585)>t_{\text {tabel }}$ $(1,994)$. Besarnya pengaruh gaya kepemimpinan transformasional terhadap kinerja karyawan adalah 0,215 atau sebesar $21,5 \%$ dianggap signifikan yang dibuktikan dengan taraf signifikansi sebesar $0,012<0,05$.

Hasil penelitian ini menunjukkan bahwa dengan meningkatkan fungsi gaya kepemimpinan transformasional maka kinerja karyawan akan meningkat. Hasil penelitian ini sesuai dengan pendapat Yang \& Islam (2012: 388), bahwa kepemimpinan transformasional adalah kepemimpinan yang menginspirasi, membangkitkan dan mengubah orang-orang atau karyawan dengan visi dan semangat untuk mencapai suatu tujuan dengan menyuntikkan antusiasme dan energi untuk menyelesaikan sesuatu. Hasil penelitian ini juga didukung oleh penelitian yang dilakukan oleh Masadeh et al. (2016), yang menyimpulkan bahwa gaya kepemimpinan transformasional secara positif berpengaruh terhadap kinerja karyawan.

\section{Pengaruh Budaya Organisasi Terhadap Kinerja Karyawan}

Budaya organisasi berpengaruh positif dan signifikan terhadap kinerja karyawan. Hasil pengujian hipotesis ini dibuktikan dengan nilai $t_{\text {hitung }}(10,940)>t_{\text {tabel }}(1,994)$. Besarnya pengaruh budaya organisasi terhadap kinerja karyawan adalah 0,580 atau sebesar $58,0 \%$ dianggap signifikan yang dibuktikan dengan taraf signifikansi $0,000<0,05$.

Hasil penelitian ini menunjukkan bahwa dengan menciptakan budaya organisasi yang baik dalam bekerja maka kinerja karyawan akan meningkat. Hal ini sesuai dengan hasil penelitian yang dilakukan oleh Tri Maryati et al. (2019) dan penelitian yang dilakukan oleh Shahzad et al. (2013) yang menyimpulkan bahwa budaya organisasi berpengaruh positif dan signifikan terhadap kinerja karyawan. 
Berdasarkan hasil uji deskriptif penelitian ini, indikator-indikator yang paling berpengaruh dalam menciptakan budaya organisasi yang baik untuk meningkatkan kinerja karyawan di PT. Champion Kurnia Djaja Technologies adalah dengan meningkatkan inisiatif karyawan dalam bekerja agar tidak selalu bergantung pada petunjuk pimpinan untuk menyelesaikan pekerjaan yang seharusnya bisa dilakukan sendiri oleh karyawan. Peningkatan inisiatif tersebut dapat dilakukan dengan cara melakukan bimbingan dan melalui pelatihan peningkatan kompetensi karyawan.

\section{Pengaruh Kepuasan Kerja Terhadap Kinerja Karyawan}

Kepuasan kerja berpengaruh positif dan signifikan terhadap kinerja karyawan. Hasil pengujian hipotesis ini dibuktikan dengan nilai $t_{\text {hitung }}(2,544)>t_{\text {tabel }}(1,994)$. Besarnya pengaruh kepuasan kerja terhadap kinerja karyawan adalah 0,354 atau sebesar 35,4\% dianggap signifikan yang dibuktikan dengan taraf signifikansi sebesar 0,013 $<0,05$.

Hasil penelitian ini sesuai dengan pendapat Edison dkk (2018: 210), bahwa kepuasan kerja yang tinggi akan membentuk suasana yang nyaman dan semangat kerja yang tinggi. Sebaliknya, rusaknya kondisi kerja dan rendahnya kepuasan kerja akan dapat mengakibatkan rendahnya komitmen karyawan dan akhirnya mempengaruhi kinerja karyawan yang bersangkutan. Jika ketidakpuasan ini dibiarkan berkembang, suasana lingkungan kerja akan menjadi keruh dan tim akan menjadi rapuh. Oleh sebab itu kinerja karyawan dapat ditingkatkan dengan meningkatkan kepuasan kerja karyawan.

Berdasarkan hasil uji linieritas pengaruh kepuasan kerja terhadap kinerja karyawan, didapatkan bahwa model hubungan tersebut tidak sepenuhnya linier (linier parsial). Untuk $23,0 \%$ responden yang berada pada tingkat kepuasan kerja yang sangat tinggi, kepuasan kerja tidak lagi dapat meningkatkan kinerja tetapi akan menurunkan kinerja karyawan tersebut karena sudah merasa sangat puas dengan pekerjaannya. Berikut ini adalah hasil analisis jawaban responden mengenai indikator-indikator kepuasan kerja yang memilih skala tertinggi (4-5) dengan frekuensi terbanyak, diantaranya:

- Pekerjaan sangat menarik dan menyenangkan.

Perlu dilakukan review terhadap tugas dan tanggung jawab karyawan secara berkala apakah karyawan tersebut sudah berkontribusi terhadap perusahaan sesuai tugas dan tanggung jawabnya. Sebagai solusi, sistem rotasi dapat dilakukan sesuai bakat, kemauan dan kemampuan karyawan untuk menciptakan suasana baru yang lebih sesuai sehingga karyawan menjadi lebih berkembang dan kepuasan kerja yang baru akan terbentuk dan akhirnya berdampak kepada peningkatan kinerja karyawan kembali.

- Karyawan diberi kepercayaan dalam bekerja.

Kepercayaan yang diberikan kepada karyawan dalam bekerja harus tetap berada dalam norma kerja dan dikontrol dengan baik. Kepercayaan penuh tanpa pengontrolan biasanya dapat disalahgunakan oleh karyawan dan membuatnya bekerja sesuai dengan kemauan sendiri. Jika kondisi seperti ini dibiarkan maka akan dapat menciptakan suasana kerja yang tidak terkontrol dan pada akhirnya karyawan tidak fokus lagi dalam bekerja dan kinerjanya bisa menjadi menurun. Oleh sebeb itu fungsi pengontrolan harus tetap dijalankan bersamaan dengan kepercayaan yang diberikan kepada karyawan.

- Atasan selalu membantu karyawan bila mendapat kesulitan dalam pekerjaan.

Atasan sudah seharusnya memberikan bantuan terhadap bawahan yang mendapatkan kesulitan dalam bekerja. Namun, bantuan yang diberikan atasan sebaiknya tidak membuat karyawan merasa dimanja sehingga membuat karyawan tersebut menjadi kurang bertanggung jawab dan kinerjanya menjadi menurun. Bantuan yang diberikan sebaiknya bersifat mendidik dan dapat meningkatkan wawasan serta kompetensi agar karyawan mampu menangani persoalan yang sama di kemudian hari. 


\section{Pengaruh Motivasi Terhadap Kinerja Karyawan Melalui Kepuasan Kerja}

Motivasi berpengaruh positif terhadap kinerja karyawan melalui kepuasan kerja sebagai variabel intervening. Hasil pengujian hipotesis ini dibuktikan dengan nilai $t_{\text {hitung }}(2,406)$ $>t_{\text {tabel }}(1,994)$. Besarnya pengaruh motivasi terhadap kinerja karyawan melalui kepuasan kerja adalah 0,103 atau sebesar $10,3 \%$. Hasil penelitian ini menunjukkan bahwa kepuasan kerja mampu bertindak sebagai variabel intervening untuk memediasi hubungan motivasi terhadap kinerja karyawan. Hubungan langsung variabel motivasi terhadap kinerja karyawan yang bersifat negatif dapat diubah menjadi positif melalui kepuasan kerja sebagai variabel intervening.

\section{Pengaruh Gaya Kepemimpinan Transformasional Terhadap Kinerja Karyawan Melalui Kepuasan Kerja}

Gaya kepemimpinan transformasional berpengaruh positif terhadap kinerja karyawan melalui kepuasan kerja sebagai variabel intervening. Hasil pengujian hipotesis ini dibuktikan dengan nilai thitung $(2,493)>t_{\text {tabel }}(1,994)$. Besarnya pengaruh gaya kepemimpinan transformasional terhadap kinerja karyawan melalui kepuasan kerja adalah 0,178 atau sebesar 17,8\%. Hasil penelitian ini menunjukkan bahwa kepuasan kerja mampu bertindak sebagai variabel intervening untuk memediasi hubungan gaya kepemimpinan transformasional terhadap kinerja karyawan, namun hasilnya tidak sebesar pengaruh langsung variabel gaya kepemimpinan transformasional terhadap kinerja karyawan.

\section{Pengaruh Budaya Organisasi Terhadap Kinerja Karyawan Melalui Kepuasan Kerja}

Budaya organisasi berpengaruh positif terhadap kinerja karyawan melalui kepuasan kerja sebagai variabel intervening. Hasil pengujian hipotesis ini dibuktikan dengan nilai $t_{\text {hitung }}$ $(2,425)>t_{\text {tabel }}(1,994)$. Besarnya pengaruh budaya organisasi terhadap kinerja karyawan melalui kepuasan kerja adalah 0,096 atau sebesar 9,6\%. Hasil penelitian ini menunjukkan bahwa kepuasan kerja mampu bertindak sebagai variabel intervening untuk memediasi hubungan budaya organisasi terhadap kinerja karyawan, namun hasilnya tidak sebesar pengaruh langsung variabel budaya organisasi terhadap kinerja karyawan.

\section{Kesimpulan dan Saran}

\section{Kesimpulan}

Berdasarkan hasil analisis deskriptif dan analisis statistik serta pembahasan dalam penelitian ini, maka dapat diambil kesimpulan sebagai berikut:

1. Motivasi berpengaruh positif dan signifikan terhadap kepuasan kerja karyawan di PT. Champion Kurnia Djaja Technologies.

2. Gaya kepemimpinan transformasional berpengaruh positif dan signifikan terhadap kepuasan kerja karyawan di PT. Champion Kurnia Djaja Technologies.

3. Budaya organisasi berpengaruh positif dan signifikan terhadap kepuasan kerja karyawan di PT. Champion Kurnia Djaja Technologies.

4. Motivasi berpengaruh negatif dan signifikan terhadap kinerja karyawan di PT. Champion Kurnia Djaja Technologies.

5. Gaya kepemimpinan transformasional berpengaruh positif dan signifikan terhadap kinerja karyawan di PT. Champion Kurnia Djaja Technologies.

6. Budaya organisasi berpengaruh positif dan signifikan terhadap kinerja karyawan di PT. Champion Kurnia Djaja Technologies. 
7. Kepuasan kerja berpengaruh positif dan signifikan terhadap kinerja karyawan di PT. Champion Kurnia Djaja Technologies.

8. Motivasi berpengaruh positif terhadap kinerja karyawan melalui kepuasan kerja karyawan di PT. Champion Kurnia Djaja Technologies.

9. Gaya kepemimpinan transformasional berpengaruh positif terhadap kinerja karyawan melalui kepuasan kerja karyawan di PT. Champion Kurnia Djaja Technologies.

10. Budaya Organisasi berpengaruh positif terhadap kinerja karyawan melalui kepuasan kerja karyawan di PT. Champion Kurnia Djaja Technologies.

\section{Saran-Saran}

Berdasarkan hasil penelitian ini mengenai "Pengaruh motivasi, gaya kepemimpinan transformasional dan budaya organisasi terhadap kinerja karyawan melalui kepuasan kerja sebagai variabel intervening - Studi pada PT. Champion Kurnia Djaja Technologies", maka disarankan sebagai berikut:

1. Untuk meningkatkan kinerja karyawan melaui motivasi kerja di PT. Champion Kurnia Djaja Technologies, disarankan menggunakan kepuasan kerja sebagai variabel intervening (mediasi), dengan lebih memperhatikan indikator-indikator berikut ini:

- Agar pimpinan tidak membeda-bedakan karyawan dan semuanya mendapatkan perhatian yang sama.

- Agar pimpinan selalu memberikan dukungan penuh kepada karyawannya untuk pengembangan diri.

2. Untuk memberikan efek positif pengaruh motivasi terhadap kinerja karyawan secara langsung di PT. Champion Kurnia Djaja Technologies, maka disarankan:

- Melakukan rotasi secara berkala sehingga karyawan bisa mendapatkan suasana baru yang lebih menantang dalam bekerja.

- Memberikan pelatihan berkala kepada karyawan sehingga karyawan menjadi lebih terampil dalam bekerja dan menghasilkan kualitas kerja sesuai dengan standar yang sudah ditetapkan.

- Memberikan target waktu penyelesaian pekerjaan, melakukan pengontrolan dan mengevaluasi kinerja karyawan secara berkala sehingga karyawan menjadi lebih disiplin dan dapat menyelesaikan pekerjaannya tepat waktu.

3. Dalam meningkatkan kinerja karyawan melalui kepuasan kerja sebagai variabel intervening, maka disarankan:

- Melakukan review terhadap tugas dan tanggung jawab karyawan secara berkala apakah karyawan tersebut sudah berkontribusi terhadap perusahaan sesuai dengan tugas dan tanggung jawabnya.

- Melakukan pengontrolan terhadap kepercayaan penuh yang diberikan kepada karyawan agar kepercayaan yang diberikan tidak disalahgunakan.

- Setiap bantuan yang diberikan oleh atasan kepada bawahan harus bersifat mendidik dan dapat meningkatkan wawasan serta kompetensi agar bawahan mampu menangani persoalan yang sama di kemudian hari.

4. Disarankan agar PT. Champion Kurnia Djaja Technologies menerapkan gaya kepemimpinan transformasional untuk meningkatkan kepuasan kerja dan kinerja karyawan dengan menggunakan indikator-indikator kepemimpinan transformasinal yang digunakan dalam penelitian ini karena hasilnya berpengaruh positif dan signifikan.

5. Disarankan agar PT. Champion Kurnia Djaja Technologies selalu menciptakan, menjaga, dan mempertahankan budaya organisasi yang baik untuk meningkatkan kepuasan kerja dan kinerja karyawan dengan menggunakan indikator-indikator yang digunakan dalam penelitian ini karena hasilnya terbukti berpengaruh positif dan signifikan. 


\section{Daftar Pustaka}

Agus, M. (2017), "Pengaruh Gaya Kepemimpinan Transformasional, Kompensasi dan Motivasi Kerja Terhadap Kinerja Pegawai Pada Kantor Kesyahbandaran Dan Otoritas Pelabuhan Pantoloan". Jurnal Katalogis, Volume 5 Nomor 7, 36-43.

Antasurya, R. (2013), “Analisis Pengaruh Kepemimpinan Transaksional dan Motivasi Kerja Terhadap Kepuasan Kerja Setra Dampaknya Pada Kinerja Pegawai (Studi pada Kanwil DJP Jawa Tengah I Kota Semarang)”. Jurnal Bisnis Strategi, Vol. 22 No. 2 Desember 2013.

Bahri, S. (2018), "Metode Penelitian Bisnis - Lengkap Dengan Teknik Pengolahan Data SPSS". Yogyakarta: Andi Offset.

Dharma, Y. (2017), "The Effect of Work Motivation on the Employee Performance with Organization Citizenship Behavior as Intervening Variable at Bank Aceh Syariah”. Emerald Reach Proceedings Series, Vol.1, 7-12, (c Emerald Publishing Limited 25162853, DOI 10.1108/978-1-78756-793-1-00065.

Diamantidis, A.D. \& Chatzoglou, P. (2018), "Factors affecting employee performance: an empirical approach". International Journal of Productivity and Performance Management (C) Emerald Publishing Limited 1741-0401, DOI 10.1108/IJPPM-012018-0012.

Edison, E. dkk (2018), "Manajemen Sumber Daya Manusia”. Bandung: Alfabeta.

Gaol, J. L. (2014), “A to Z Human Capital - Manajemen Sumber Daya Manusia”. Jakarta: PT. Grasindo Anggota Ikapi.

Ghozali, I. (2018), "Aplikasi Analisis Multivariat Dengan Program IBM SPSS 25, Edisi Kesembilan". Semarang: Universitas Diponegoro.

Hamali, A. Y. (2018), "Pemahaman Manajemen Sumber Daya Manusia”. Jakarta: Buku Seru. Magfirah (2019), "Pengaruh Gaya Kepemimpinan Transformasional, Motivasi Kerja dan Organizational Citizenship Behavior Terhadap Kinerja Karyawan Pada PT. BNI Cabang Palu". Jurnal Katalogis, Volume 3, Nomor 10, 78-87.

Mangkunegara, A.P (2017), "Manajemen Sumber Daya Manusia Perusahaan, Cetakan Keempatbelas". Bandung: PT. Remaja Rosdakarya.

Maryati, T. et al. (2019), "The Effect of Spiritual Leadership and Organizational Culture on Employee Performance: The Mediating Role of Job Satisfaction". International Journal of Innovation, Creativity and Change. Volume 9, Issue 3. Diakses dari: www.ijicc.net

Masadeh, R. et al. (2016), "A Jordanian empirical study of the associations among transformational leadership, transactional leadership, knowledge sharing, job performance, and firm performance: a structural equation modelling approach”. Journal of Management Development, Vol. 35 Iss 5 pp. () Emerald Group Publishing Limited. Diakses dari: http://dx.doi.org/10.1108/JMD-09-2015-0134

Parmin (2015), "Pengaruh Kepemimpinan, Motivasi Kerja, dan Budaya Organisasi Terhadap Kinerja Karyawan Dengan Kepuasan Kerja Sebagai Variabel Intervening (Studi Pada Karyawan Yantek Unit PT. PLN Rayon Kebumen)". Jurnal Fokus Bisnis, Volume 14, No. 02, Desember 2015.

Pawirosumarto, S. et al. (2017), "The effect of work environment, leadership style, and organizational culture towards job satisfaction and Its implication towards employee performance in Parador Hotels and Resorts, Indonesia”. International Journal of Law and Management, (C) Emerald Group Publishing Limited. Diakses dari: https://doi.org/10.1108/IJLMA-10-2016-0085

Puni, A. et al. (2018), "Transformational leadership and job satisfaction: the moderating effect of contingent reward". Leadership \& Organization Development Journal (C) Emerald 
Group Publishing Limited 0143-7739. Diakses dari: https://doi.org/10.1108/LODJ-112017-0358

Setiawan, D. (2013), "Pengaruh Gaya Kepemimpinan Transformasional dan transaksional Terhadap Kepuasan Kerja dan Kinerja Karyawan di PT. Tohitindo Multi Craft Industries Krian”. Jurnal Ilmiah Mahasiswa Manajemen Vol. 2 No.1.

Shahzad, F. et al. (2013), "Impact of Organizational Culture on Employees Job Performance: An Empirical Study of Software Houses in Pakistan”. Journal of Business Studies Quarterly.

Sugiyono (2019), "Metode penelitian kuantitatif, Kualitatif dan R\&D (Cetakan Ke-1)". Bandung: Alfabeta.

Wibowo (2016), "Manajemen Kinerja - Edisi Kelima”. Jakarta: PT. Raja Grafindo Persada.

Yang, Y.F. \& Islam, M. (2012), "The influence of transformational leadership on job satisfaction: The balanced scorecard perspective". Journal of Accounting \& Organizational Change, Vol. 8, No. 3, 386-402, () Emerald Group Publishing Limited 1832-5912. Diakses dari: http://dx.doi.org/10.1108/18325911211258353 